\title{
Anticlastogenic potential and antioxidant effects of an aqueous extract of pulp from the pequi tree (Caryocar brasiliense Camb)
}

\author{
Juliana Khouri ${ }^{1}$, Inês S. Resck ${ }^{2}$, Marcio Poças-Fonseca ${ }^{1}$, Thiago M.M. Sousa ${ }^{1}$, Luciana O. Pereira ${ }^{1}$, \\ Adriano B.B. Oliveira ${ }^{1}$ and Cesar K. Grisolia ${ }^{1}$ \\ ${ }^{1}$ Departamento de Genética e Morfologia, Instituto de Ciências Biológicas, Universidade de Brasília, \\ Brasilia, DF, Brazil. \\ ${ }^{2}$ Laboratório de Química Orgânica, Instituto de Química, Universidade de Brasília, Brasília, DF, Brazil.
}

\begin{abstract}
The effectiveness of an aqueous extract of Caryocar brasiliense (Caryocaraceae) Camb pulp, popularly known in Brazil as pequi, against clastogenicity induced by cyclophosphamide and bleomycin was evaluated using an in vivo mouse bone marrow cell micronuclei test, an in vitro Chinese hamster ovary cell (CHO-K1) chromosome aberration test and an in vitro antioxidant assay based on the oxidative damage to 2-deoxy-D-ribose (2-DR) induced by hydroxyl radicals $\left({ }^{\circ} \mathrm{OH}\right)$ generated by the reaction between ascorbic acid and (Fe III)-EDTA. In mouse bone marrow cells the extract showed a protective effect against micronuclei induced by cyclophosphamide and bleomycin but did not interfere with polychromatic bone marrow erythrocyte proliferation, except when the mice had been treated with the highest dose of cyclophosphamide. When CHO-K1 cells were pretreated by adding $0.01,0.05$ or $0.1 \mathrm{~mL}$ of extract per mL of cell culture medium 24 or $48 \mathrm{~h}$ before bleomycin or cyclophosphamide there was a protective effect against chromosome breaks and a significant decrease in the mitotic index (a measure of cytotoxicity) of the CHO-K1 cells. The extract also had a protective effect against oxidative hydroxyl radical damage to 2-DR. This study suggests that $C$. brasiliense pulp aqueous extract has anticlastogenic potential, possibly due to its antioxidative properties.
\end{abstract}

Key words: Caryocar brasiliense, anticlastogenicity, antioxidant, micronucleus.

Received: April 11, 2006; Accepted: September 29, 2006.

\section{Introduction}

Medicinal plants often represent the only therapeutic resource for many communities and ethnic groups. In the Brazilian savannah (the cerrado), Caryocar brasiliense Camb., popularly known as pequi, is a common tree frequently used in folk medicine to treat many types of ailment, such as influenza, asthma and other respiratory diseases. The pulp of the fruit of this tree is often used in the regional cooking in typical dishes such as "rice with pequi" and contains many compounds with antioxidant properties (Facioli and Gonçalves, 1998; Azevedo-Meleiro and Rodrigues-Amaya, 2004)

Due to the high biodiversity of tropical and subtropical areas Latin America has many plant foods rich in carotenes. However, particularly in Brazil, there is a serious threat that carotenoid-rich indigenous species may be supplanted by introduced crops with a lower carotenoid con-

Send correspondence to Cesar K. Grisolia. Departamento de Genética e Morfologia, Instituto de Ciências Biológicas, Universidade de Brasília, 70910-900 Brasília, DF, Brazil. E-mail: grisolia@unb. br. tent and disappear (Rodrigues-Amaya, 1999). Natural antioxidant compounds in the human diet may prevent the genetic effects of mutagens and carcinogens and many studies have shown that an increased intake of fruits or vegetables rich in antioxidants decreases the level of oxidative DNA damage (Duthie et al. 1996; Collins et al. 2001; Dusinská et al. 2003). Extracts of the plant Toxicodendron quercifolium (poison-ivy, eastern poison-oak) and the mushroom Agaricus blazei (the Brazilian sun-mushroom) have shown antigenotoxic activity when examined using the in vivo mouse bone marrow micronucleus assay and the in vitro Chinese hamster ovary cell (CHO-K1) chromosome aberration assay (Mersch-Sundermann et al. 2004; Guterres et al. 2005; Bellini et al. 2006). Edenharder et al. (2002) used various test-systems for the evaluation of genotoxicity to demonstrate the protective effects of plant beverages, fruits, vegetables and spices against genotoxicity induced by 2-acetylaminofluorene or 2-amino-1methyl-6-phenylimidazo[4,5-b]pyridine and Edenharder et al. (2003) reported that homogenates of spinach, artichoke, peaches and black grapes reduced micronuclei (MN) induction in mouse bone marrow treated with benzo[a]pyrene. 
Many studies with Brazilian plants used in folk medicine have shown antimutagenic properties due to a range of substances that act as antioxidants. Nascimento et al. (2006) reported that leaf extracts of Turnera ulmifolia, used in Brazilian folk medicine for their anti-inflammatory activity, reduce spontaneous lipid peroxidation in rat brain homogenates as measured using the thiobarbituric acid reactive substrates (TBARS - method, Janero 1990). Delmanto et al., (2001) demonstrated that the edible mushroom A. blazei, consumed as a food or tea, has anticlastogenic activity against in vivo clastogenicity induced by cyclophosphamide. Nogueira et al. (2006) reported that the flower extract of Melampodium divaricatum (known in Brazil as the false-Calendula, or false-marigold) is used in Brazil as an anti-inflammatory agent and possess chemopreventive properties when tested in different strains of Salmonella typhimurium. Bleomycin sulfate is an glycopeptide antibiotic used in cancer chemotherapy and has been shown to be a potent radiomimetic antibiotic which induces micronuclei in humans, rats and mice through the induction of oxidative DNA damage (Erexson et al., 1995). The active mechanism of bleomycin has been related to the activation of molecular oxygen in the presence of ferrous iron, producing oxygen radicals such as superoxide anions which are toxic and mutagenic in a variety of in vitro and in vivo test systems (Sausville et al. 1978; Albertini and Gurnier-Suillerot 1984; Sikic 1986). Cyclophosphamide is an alkylating agent used to treat a wide range of neoplastic diseases and also as an immunosuppressive agent prior to organ transplantation (Anderson et al. 1995). Hepatic mixed function oxidases activate cyclophosphamide, the major anti-neoplastic metabolite of cyclophosphamide degradation being phospharamide mustard which binds to DNA forming labile covalent DNA adducts and cross-links (Anderson et al. 1995). Cyclophosphamide has been widely used as a positive control in the single-dose mouse micronuclei assay because it induces a variety of changes in genetic material (IARC 1981; Krishna et al. 1987).

During the study described in this paper we assessed the anticlastogenic potential of $C$. brasiliense using the two known clastogens bleomycin and cyclophosphamide and the in vivo mouse bone marrow micronucleus assay and the in vitro Chinese hamster ovary cell chromosome aberration assay. We also assessed antioxidant properties using the degradation of 2-deoxyribose in the Fenton reaction assay.

\section{Material and Methods}

\section{Materials}

Fresh Caryocar brasiliense Camb (Caryocaraceae) fruits was purchased from a local market in January/ Febuary Brasília and aqueous extracts obtained by extracting $100 \mathrm{~g}$ (wet weight) of the pulp in $1000 \mathrm{~mL}$ of distilled water using Soxhlet extraction for $10 \mathrm{~h}$ under an argon atmosphere. After extraction the aqueous extract (henceforth called simply 'the extract') was immediately frozen at $-85^{\circ} \mathrm{C}$ and stored until needed. Bleomycin (Chemical Abstracts Service (CAS) registry number 011056-06-7) was obtained as Bleoxane sulfate (Bristol-Myers, USA) and cyclophosphamide (CAS 6055-19-2) as Genuxal (ASTA Medica Laboratory, Brazil). This project was approved by the Animal Ethics Committee of Institute of Biological Sciences of the University of Brasilia.

\section{Swiss mouse micronucleus test}

Swiss albino mice of both sexes (60 days old and weighing $30 \pm 2 \mathrm{~g}$ ) were obtained from the Central Animal Facility of the University of Brasilia and randomly allocated to groups M1 to M10 as shown in Table 1, each group consisting of eight mice. Extract was administered to the mice orally, either alone or in combination with single intraperitoneal injections of bleomycin diluted in $\mathrm{NaCl}$ $0.9 \%$ or aqueous cyclophosphamide, see Table 1 for dosage. A control group (M1) was given water in place of extract and no clastogens were administered. The animals were sacrificed by cervical dislocation and slides of bone marrow cells were prepared according to a standard method (Schmid, 1975). The frequency of micronuclei (MN) in polychromatic erythrocytes (PCE) and the ratio of polychromatic erythrocytes to total erythrocytes (\%PCE) were estimated by scoring 1000 PCE per animal. Results were analyzed using the Mann-Whitney $U$ test with $\alpha=0.05$.

\section{The 2-deoxyribose degradation assay}

The formation of hydroxyl radicals ( $(\mathrm{OH})$ by Fenton reagents was quantified based on the oxidative degradation of 2-deoxyribose (2-DR) and the quantification of its degradation product (malonaldehyde) by condensation with 2-thiobarbituric acid-TBARS method (Janero, 1990). The typical reaction was started by adding $\mathrm{Fe}(\mathrm{II})$ at a final concentration of $6 \mu \mathrm{M}$ to a $0.5 \mathrm{~mL}$ final volume of $20 \mathrm{mM}$ phosphate buffer, $5 \mathrm{mM}$ of 2-deoxyribose, $\mathrm{Cu}(\mathrm{II})(5 \mu \mathrm{M})$ $(\mathrm{pH}=7.2)$ and $100 \mu \mathrm{M} \mathrm{H}_{2} \mathrm{O}_{2}$ with and without $10 \mu \mathrm{M}$ of ascorbate as an iron chelator. Reactions were carried out for 10 min at $25^{\circ} \mathrm{C} \pm 1{ }^{\circ} \mathrm{C}$ and were stopped by adding of $0.5 \mathrm{~mL}$ of $50 \mathrm{mM} \mathrm{NaOH}$ containing $4 \%(\mathrm{w} / \mathrm{v})$ phosphoric acid. After boiling for $15 \mathrm{~min}$, the absorbance of the solution containing the 2-DR oxidation products was measured at $532 \mathrm{~nm}$ using an Hitachi U-2001 spectrophotometer. Assays were conducted by adding 10,20,30, 4050,100 or $200 \mu \mathrm{L}$ of extract to the mixture described above (without ascorbate), pre-incubating for $30 \mathrm{~min}$ at $25^{\circ} \mathrm{C} \pm 1{ }^{\circ} \mathrm{C}$ and then adding $100 \mu \mathrm{M}$ ascorbate, incubating for $12 \mathrm{~min}$ and stopping the reaction and measuring the absorbance as described above. Spectra of the extract complexed with Fe(II) or Fe(III) were obtained by pre-incubating the complexes in the phosphate buffer described above for one hour and measuring the absorbance at $532 \mathrm{~nm}$ in the absence of iron against blanks of buffer and buffer containing the same 
Table 1 - The number of polychromatic erythrocytes as a percentage of the total number of erythrocytes (the proliferation index) and the mean number of micronuclei in polychromatic and normochromatic erythrocytes of Swiss albino mice of both sexes treated orally with $0.03 \mathrm{~mL}$ of Caryocar brasiliense (pequi) aqueous extract, equivalent to $1 \mathrm{~mL} \mathrm{~kg}^{-1}$ body weight (bw), alone or with a single intraperitoneal bleomycin or cyclophosphamide injection administered $20 \mathrm{~h}$ before sacrifice for bleomycin and $24 \mathrm{~h}$ before sacrifice for cyclophosphamide. Each group contained eight mice. Significant differences by the Mann-Whitney $U$ test are shown for the polychromatic erythrocytes.

\begin{tabular}{|c|c|c|c|c|}
\hline \multirow[b]{2}{*}{ Group } & \multirow[b]{2}{*}{ Treatment } & \multicolumn{2}{|c|}{$\begin{array}{l}\text { Polychromatic } \\
\text { erythrocytes }\end{array}$} & \multirow{2}{*}{$\begin{array}{c}\begin{array}{c}\text { Normochromatic } \\
\text { erythrocytes }\end{array} \\
\begin{array}{c}\text { Mean number of } \\
\text { micronuclei }\end{array}\end{array}$} \\
\hline & & Proliferation index & $\begin{array}{l}\text { Mean number of } \\
\text { micronuclei }\end{array}$ & \\
\hline M1 & Control (distilled water) & 43.6 & $1.3 \pm 0.3$ & $1.3 \pm 0.2$ \\
\hline M2 & Extract $^{1}, 0.03 \mathrm{~mL}$ orally for 10 days & 51.4 & $1.4 \pm 0.4$ & $2.1 \pm 0.5$ \\
\hline M3 & Bleomycin, $50 \mathrm{mg} \mathrm{kg}^{-1}$ bw $20 \mathrm{~h}$ before sacrifice & 61.2 & $3.4 \pm 0.6^{*}$ & $1.1 \pm 0.3$ \\
\hline M4 & Extract as for M2 then bleomycin as in M3 & 53.5 & $1.7 \pm 0.3^{\dagger}$ & $0.4 \pm 0.2$ \\
\hline M5 & Bleomycin, $100 \mathrm{mg} \mathrm{kg}^{-1}$ bw. $20 \mathrm{~h}$ before sacrifice & 55.2 & $9.0 \pm 4.6^{*}$ & $3.0 \pm 1.3$ \\
\hline M6 & Extract as for M2 then bleomycin as in M5 & $38.3^{-}$ & $3.7 \pm 3.2^{\ddagger}$ & $2.1 \pm 0.8$ \\
\hline M7 & Cyclophosphamide $33 \mathrm{mg} \mathrm{kg}^{-1}$ bw $24 \mathrm{~h}$ before sacrifice & $28.5^{*}$ & $28.4 \pm 13.5^{*}$ & $4.6 \pm 2.2$ \\
\hline M8 & Extract as for M2 then cyclophosphamide as in M7 & 38.7 & $18.2 \pm 9.1^{\#}$ & $4.4 \pm 3.6$ \\
\hline M9 & Cyclophosphamide $66 \mathrm{mg} \mathrm{kg}^{-1}$ bw $24 \mathrm{~h}$ before sacrifice & $25.1 *$ & $54.7 \pm 27.4^{*}$ & $5.8 \pm 4.1$ \\
\hline M10 & Extract as for M2 then cyclophosphamide as in M9 & 16.7 & $39.7 \pm 21.4$ & $3.5 \pm 3.0$ \\
\hline
\end{tabular}

${ }^{1}$ Ratio of polychromatic erythrocytes to total erythrocytes. *significant at $\mathrm{p}<0.05$ compared to group M1. ${ }^{\dagger}$ significant at $\mathrm{p}<0.05$ compared to group M3. *significant at $\mathrm{p}<0.05$ compared to groups M2 and M5. "significant at $\mathrm{p}<0.05$ compared to group M7.

concentration of extract. (Gutteridge, 1981; Halliwell et al., 1987).

\section{Chinese hamster ovary cell chromosome aberration assay}

Chinese hamster ovary cells strain $\mathrm{K} 1$ (CHO-K1) were seeded in petri plates containing $10 \mathrm{~mL}$ of fresh complete HAM-F12 medium (Gibco) containing 10\% (v/v) fetal calf serum (Gibco) and grown to $70 \%$ confluence before being subjected to the treatments listed in Table 2 as groups H1 to H9. A control group (H1) was mounted without extract or added clastogens. [See notes above.] Colchicine (Sigma) was added during the last $2 \mathrm{~h}$ of incubation and all the experiments were duplicated. Cultures were harvested and by incubating at $37^{\circ} \mathrm{C}$ for $10 \mathrm{~min}$ in hypotonic $0.075 \mathrm{M}$ $\mathrm{KCl}$ and then fixed in methanol/acetic acid (3:1 v/v). Slides were stained for $10 \mathrm{~min}$ with $10 \%$ (v/v) Giemsa. One hundred metaphases were analyzed for structural chromosome aberrations (Savage, 1976) and the results were statistically evaluated using the Mann-Whitney $U$ test $(\alpha=0.05)$.

\section{Results}

The in vivo micronucleus test showed that when administered orally the extract (group M2) resulted in no statistically significant $(p=0.9369)$ increase in the number of micronuclei compared with the M1 water control group, indicating that the extract produced no clastogenic effect in respect to micronuclei frequency (Table 1).

There was also no statistically significant difference $(p=0.1)$ in the number of mouse polychromatic erythrocytes as a percentage of the total number of erythrocytes (the proliferation index) between the M1 and the M2 groups (Table1) but the proliferation index decreased in groups treated with extract plus $100 \mathrm{mg} \mathrm{kg}^{-1}$ bw bleomycin (group M6, compared to groups M2 and M5) and extract plus cyclophosphamide $66 \mathrm{mg} \mathrm{kg}^{-1}$ bw (group M10), indicating a cytotoxic effect on bone marrow cells (Table 1 ).

As expected, the groups administered clastogens without extract showed statistically significant increases in micronucleus frequency when compared to the M1 group and hence clastogenic effects (bleomycin: $\mathrm{M} 3, \mathrm{p}=0.0001$; $\mathrm{M} 5, \mathrm{p}=0.0093$. cyclophosphamide: $\mathrm{M} 7, \mathrm{p}=0.0001$; M9, $\mathrm{p}=0.009$.) and there was a marked increase in the number of micronuclei in group M5 cells, treated with $100 \mathrm{mg} \mathrm{kg}^{-1}$ bw bleomycin, as compared to group M3 treated with $50 \mathrm{mg} \mathrm{kg}^{-1}$ bw bleomycin (Table 1).

For the groups administered extract followed by bleomycin (groups M4 and M6) there was a significant decrease in the micronucleus frequency compared to their respective bleomycin-only controls ( $\mathrm{p}=0.009$ for M4 compared to $\mathrm{M} 3 ; \mathrm{p}=0.0001$ compared to M2 and M5), indicating that the extract was anticlastogenic against bleomycin-induced chromosome damage (Table 1). The M8 group administered extract followed by $33 \mathrm{mg} \mathrm{kg}^{-1}$ cyclophosphamide showed a statistically significant decrease $(p=0.009)$ in the micronuclei frequency compared to the M7 control group. However, the extract showed no statistically significant protective effect $(\mathrm{p}=0.0007)$ for the M10 group, administered extract plus $66 \mathrm{mg} \mathrm{kg}^{-1}$ bw cyclophosphamide, compared to the M9 matching cyclophosphamide control group (Table 1). The micronucleus frequency induced by cyclophosphamide in the M8 and M10 groups pre-treated with extract remained high, while the proliferation index was 
Table 2 - Number of chromosome aberrations and percentage mitotic index (MI) recorded in Chinese hamster ovary cells (CHO-K1) subjected to different in vitro treatments and treatment times with Caryocar brasiliense (pequi) aqueous extract, with or without the clastogens cyclophosphamide and bleomycin. Aliquots of the extracts were sterilized using a Millipore $0.2 \mathrm{~mm}$ nitrocellulose membrane before addition to the medium. Significant differences by the Mann-Whitney $U$ test are shown for the total aberrations and the percentage MI. Aberration key: $\mathrm{F}=$ fragment; $\mathrm{D}=$ dicentric; $\mathrm{B}^{\prime}=$ chromatid break; B" = chromosome break; CB = centromere break; and G' = chromatid gap.

\begin{tabular}{|c|c|c|c|c|c|c|c|c|c|}
\hline \multirow[b]{2}{*}{ Group } & \multirow[b]{2}{*}{ Treatments } & \multicolumn{7}{|c|}{ Chromosome aberrations } & \multirow[b]{2}{*}{ MI $(\%)$} \\
\hline & & $\mathrm{F}$ & $\mathrm{D}$ & $\mathrm{B}^{\prime}$ & B” & $\mathrm{CB}$ & G' & Total & \\
\hline H1 & Control (distilled water), assessed after $48 \mathrm{~h}$ & 08 & 01 & 04 & 02 & 00 & 01 & 16 & 2.8 \\
\hline $\mathrm{H} 2$ & Extract $0.05 \mathrm{~mL} \mathrm{~mL}^{-1}$ added $24 \mathrm{~h}$ before assessment & 05 & 02 & 00 & 01 & 01 & 02 & 11 & $1.2^{\#}$ \\
\hline H3 & Extract $0.05 \mathrm{~mL} \mathrm{~mL}^{-1}$ added $48 \mathrm{~h}$ before assessment & 08 & 00 & 01 & 02 & 05 & 04 & 20 & $1.1^{\#}$ \\
\hline $\mathrm{H} 4$ & Extract $0.01 \mathrm{~mL} \mathrm{~mL}^{-1}$ added $48 \mathrm{~h}$ before assessment & 16 & 00 & 01 & 00 & 00 & 00 & 17 & $1.9^{\#}$ \\
\hline H5 & Extract $0.1 \mathrm{~mL} \mathrm{~mL}^{-1}$ added $24 \mathrm{~h}$ before assessment & 13 & 00 & 02 & 00 & 00 & 04 & 19 & $1.4^{\#}$ \\
\hline H6 & Bleomycin $10 \mu \mathrm{g} \mathrm{mL}^{-1}$ added $20 \mathrm{~h}$ before assessment & 22 & 01 & 00 & 10 & 00 & 03 & 36 & $1.3^{\#}$ \\
\hline $\mathrm{H} 7$ & $\begin{array}{l}\text { Extract } 0.1 \mathrm{~mL} \mathrm{~mL}^{-1} \text { added } 48 \mathrm{~h} \text { before assessment plus } \\
\text { bleomycin } 10 \mu \mathrm{gL} \mathrm{mL}^{-1} \text { added } 20 \mathrm{~h} \text { before assessment }\end{array}$ & 17 & 01 & 01 & 02 & 00 & 03 & $24^{\dagger}$ & $1.0^{\#}$ \\
\hline $\mathrm{H} 8$ & Cyclophosphamide $6 \mu \mathrm{g} \mathrm{mL} \mathrm{mL}{ }^{-1}$ added $24 \mathrm{~h}$ before assessment & 25 & 00 & 00 & 01 & 07 & 00 & 33 & $1.4^{\#}$ \\
\hline H9 & $\begin{array}{l}\text { Extract } 0.1 \mathrm{~mL} \mathrm{~mL}^{-1} \text { added } 48 \mathrm{~h} \text { before assessment plus } \\
\text { cyclophosphamide } 6 \mu \mathrm{g} \mathrm{mL}^{-1} \text { added } 24 \mathrm{~h} \text { before assessment }\end{array}$ & 05 & 01 & 01 & 00 & 03 & 01 & $11^{*}$ & $0.8^{\#}$ \\
\hline
\end{tabular}

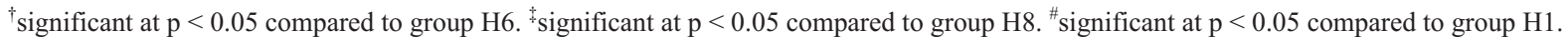

lower for both these groups than for the M1 water controls (Table 1).

In the in vitro Chinese hamster cell (CHO) experiments, there was also no evidence of chromosome aberrations indicative of clastogenicity in the $\mathrm{H} 2, \mathrm{H} 3, \mathrm{H} 4$ and $\mathrm{H} 5$ groups treated with extract as compared to the $\mathrm{H} 1$ control (Table 2) and the mitotic index of groups $\mathrm{H} 2$ to $\mathrm{H} 5$ was significantly lower $(\mathrm{p}<0.05)$ than that of the $\mathrm{H} 1$ control, indicating that the extract possessed antiproliferative activity (Table 2).

Our results indicate that bleomycin and cyclophosphamide were effective as positive DNA damage controls for the CHO-K1 method. The $\mathrm{H} 7$ group treated with extract followed by bleomycin showed a significantly lower total number of chromosome aberrations as compared to the $\mathrm{H} 6$ group treated with bleomycin only and, similarly, the H9 group treated with extract followed by cyclophosphamide showed a significantly lower total number of chromosome aberrations compared to the H8 group treated with cyclophosphamide only (Table 2). The mitotic index of the cells in groups $\mathrm{H} 2$ to $\mathrm{H} 9$ were all significantly lower than the $\mathrm{H} 1$ control (Table 2)

We also found that the extract inhibited the Fenton reaction, decreased the formation of hydroxyl radicals and reduced the oxidative degradation of 2-DR (Figure 1), probably by removing Fe(III) from EDTA by the formation of a complex with iron which is then unavailable for participation in the Fenton reaction.

\section{Discussion}

The $C$. brasiliense pulp was not analyzed by us but the main antioxidant, carotenoid and mineral composition of $C$. brasiliense has been investigated qualitatively and

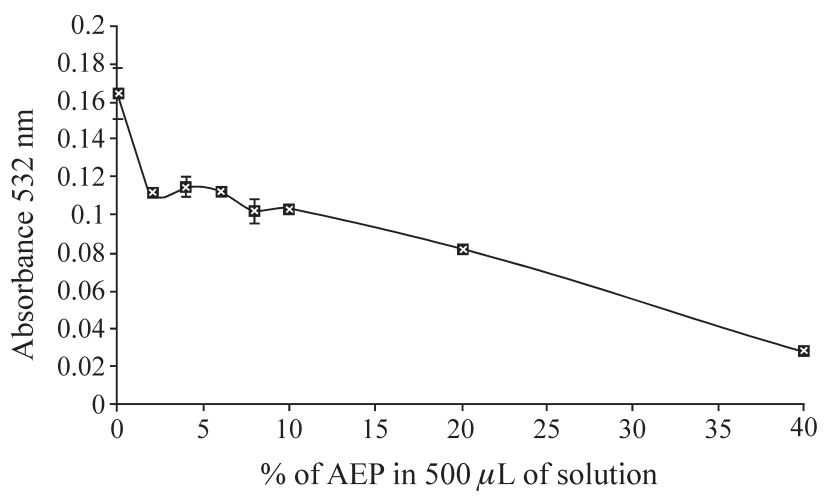

Figure 1 - Kinetics of the oxidation inhibition of 2-deoxyribose by hydrogen peroxide $\left(\mathrm{H}_{2} \mathrm{O}_{2}\right)$. Changes in absorbance $(\lambda=532 \mathrm{~nm})$ mean trapping action of AEP on hydroxyl radicals. Absorbencies were read every 5 min for $40 \mathrm{~min}$.

quantitatively using high performance liquid chromatography (Azevedo-Meleiro and Rodriguez-Amaya 2004) and the fat and vitamin composition described using gas chromatography (Facioli and Gonçalves 1998), this data being summarized Table 3.

We found that $C$. brasiliense aqueous extract showed anticlastogenic activity and was able to inhibit bleomycininduced DNA damage in mice (Table 1). Bleomycin causes various types of oxidative DNA lesions by generating reactive oxygen species (ROS) (Povirk, 1996), which have been shown to cause DNA damage, gene mutation, micronuclei formation and chromosome aberrations (Imlay and Linn, 1988; Gutteridge, 1993; Schiffl et al 1997; Cooke et al., 2003).

We found that the extract decreased the formation of hydroxyl radicals and reduced the oxidative degradation of 
Table 3 - Main antioxidant compounds, minerals and vitamins present in Caryocar brasiliense (pequi) pulp.

\begin{tabular}{|c|c|c|c|c|c|c|}
\hline \multicolumn{2}{|c|}{$\begin{array}{l}\text { Fatty acids } \\
\text { (grams per } 100 \mathrm{~g} \text { pulp) }\end{array}$} & \multicolumn{2}{|c|}{$\begin{array}{l}\text { Minerals } \\
\left(\mathrm{mg} 100 \mathrm{~g}^{-1} \text { pulp) }\right.\end{array}$} & \multicolumn{2}{|c|}{$\begin{array}{l}\text { Vitamins* } \\
\text { (mg per } 100 \mathrm{~g} \text { of pulp) }\end{array}$} & \multirow{2}{*}{$\begin{array}{l}\begin{array}{l}\text { Carotenoids } \\
\text { (unquantified) }\end{array} \\
\beta \text {-carotene }\end{array}$} \\
\hline Oleic acid & 53.9 & $\mathrm{Fe}$ & 800 & Vitamin C & 12 & \\
\hline Palmitic acid & 40.2 & $\mathrm{Ca}$ & 50 & Riboflavin & 0.46 & $\beta$-cryptoxanthin \\
\hline Stearic acid & 2.3 & $\mathrm{Na}$ & 2.1 & Niacin & 0.39 & Lutein \\
\hline Linoleic acid & 1.5 & $\mathrm{Mn}$ & 0.6 & Thiamin & 0.03 & Neoxanthin \\
\hline Palmitoleic acid & 1.4 & $\mathrm{Zn}$ & 0.5 & Vitamin A & $20000 \mathrm{U}^{*}$ & Violaxanthin \\
\hline Linolenic acid & 0.7 & $\mathrm{Cu}$ & 0.4 & & & Zeaxanthin \\
\hline \multirow[t]{3}{*}{ Araquidic acid } & 0.2 & K & 0.02 & & & \\
\hline & & $\mathrm{P}$ & 0.006 & & & \\
\hline & & $\mathrm{Mg}$ & 0.005 & & & \\
\hline
\end{tabular}

*Except for vitamin A, which is in units per $100 \mathrm{~g}$. Source: fatty acids from Facioli and Gonçalves (1998); minerals, vitamins and carotenoids from Azevedo-Meleiro and Rodrigues-Amaya (2004).

2-DR, so it is reasonable to assume that the anticlastogenic effect of the extract against bleomycin was due to its antioxidant properties. This is supported by the fact that the micronuclei induced by bleomycin are mainly due to the generation of ROS, so compounds with antioxidative activities could presumably modulate bleomycin-induced genotoxicity (Povirk and Austin, 1991; Povirk, 1996).

Cyclophosphamide clearly induced a dose-related bone marrow micronucleus response in mouse polychromatic erythrocytes and bone marrow toxicity and the in vivo treatment with $66 \mathrm{mg} \mathrm{kg}^{-1}$ bw cyclophosphamide, either alone or in combination with the equivalent of $1 \mathrm{~mL} \mathrm{~kg}^{-1}$ bw of the extract, was toxic, as shown by the decreased proliferation index (Table 1). In genotoxicity evaluations as well as antimutagenic and/or anticlastogenic studies of chemicals, the treatments should not be carried out at levels that are toxic to the cells or animals, to avoid cell-cycle inhibition. However, if no suitable data are available, a range finding is performed because dose levels should cover a range from the maximum to little or not toxicity (US-EPA, 1998). Since cyclophosphamide is an alkylating agent that is metabolized to phospharamide mustard which damages DNA by forming labile covalent DNA adducts and cross-links while bleomycin produces hydroxy radicals the fact that in this study the extract was a more efficient anticlastogen against bleomycin than cyclophosphamide supports the hypothesis that antioxidants in the extract inhibited chemical mutagenesis in vivo. These results are in agreement with many other studies showing that ingredients present in plant extracts have antioxidant properties which can protect DNA against damage caused by free radicals (Owen et al., 2003; Cano et al., 2003; Lee et al., 2003). In the CHO-k1 cell experiments the reduced mitotic index indicated that bleomycin, cyclophosphamide and extract induced a substantial delay in the cell-cycle, while the pretreatment of cells with extract before the addition of bleomycin or cyclophosphamide depressed the mitotic index even further. This interference with the cell- cycle would be expected to result in a lower yield of chromosome aberrations. The indirectly-acting mutagen cyclophosphamide must be metabolically transformed to interact with DNA but in our system the CHO-k1 cells were sensitive to cyclophosphamide even without the S-9 mix activation system. This data supports the observations of some workers who unexpectedly reported that cyclophosphamide exhibited in vitro clastogenic activity in cultured rat, rabbit and human lymphocytes without exogenous metabolic activation (Ikeuchi and Sasaki,1981; Abe et al. , 1983; Dearfiled et al., 1983), raising the question of whether or not the observed clastogenic effects were due to the spontaneous hydrolysis of cyclophosphamide known to occur at temperatures above $30^{\circ} \mathrm{C}$ (Mohn and Ellenberger, 1976; Anderson 1995). In our study, in vitro anticlastogenicity was observed in conjunction with specific cytotoxicity as shown by the significant reduction in the mitotic index as compared to the $\mathrm{H} 1$ untreated control (Table 2). However, our in vivo study indicated more clearly that the extract had a protective effect against bleomycin-induced oxidative damage. According to Liu et al. (2003) and Berger (2005), an antioxidant dietary supplement can reduce the level of DNA oxidative damage and protect normal cells against the adverse side-effects of some cancer chemotherapy protocols.

The 2-deoxyribose degradation assay supports the data (Figure 1) on the in vivo and in vitro antioxidant effect of the extract and its ability to scavenge hydroxyl radicals. The fact that the extract was able to reduce Fe(III) to Fe(II) suggests that redox cycling of Fe(III) formed by the Fenton reaction could have occurred and that the extract was able to prevent the generation of the hydroxy radicals and 2-deoxyribose oxidative damage induced by Fenton reagents. The kinetics of the inhibition of 2-deoxyribose oxidation by $\mathrm{H}_{2} \mathrm{O}_{2}$ are shown in Figure 1, which shows the decrease in absorbance and hence the mean trapping action of the extract on hydroxyl radicals. This mechanism has been used for the quantification of antioxidant properties of many 
compounds present in fruits and vegetables (Lopes, 1999). Our observations on the antioxidant activity of $C$. brasiliense aqueous extract may in part explain the anticlastogenic potential of this compound.

\section{Acknowledgments}

We thank the Brazilian agency FINATEC and University of Brasilia (FUNPE) for financial support and CNPq (PIBIC) for the fellowship to Adriano B.B. de Oliveira. We also thank Marcelo Hermes-Lima, Cezar S. Gomes and Concepta McManus Pimentel for important collaboration and Maisa Borges Costa for technical assistance.

\section{References}

Abe S, Nemoto N and Sasaki M (1983) Induction by indirect mutagens/carcinogens, aryl hydrocarbon hydroxylase activity and benzo[a]pyrene in cultured human hepatoma cells. Mutat Res 109:83-90.

Albertini JP and Gurnier-Suillerot A (1984) Iron-BLM deoxyribonucleic acid system. Evidence of deoxyribonucleic and interaction with amine groups of the beta-amino alanine moiety. Biochem 23:47-55.

Anderson D, Bishop JB, Garner RC, Ostrosky-Wegman P and Selby PB (1995) Cyclophosphamide: Review of its mutagenicity for an assessment of potential germ cell risks. Mutat Res 330:115-181.

Bellini MF, Angeli JPF, Matuo R, Terezan AP, Ribeiro LR and Mantovani MS (2006) Antigenotoxicity of Agaricus blazei mushroom organic and aqueous extracts in chromosomal aberrations and cytokinesis block micronucleus in CHO-k1 cells. Toxicol in Vitro 20:355-360.

Azevedo-Meleiro CH and Rodriguez-Amaya DB (2004) Confirmation of the identity of the carotenoids of tropical fruits by HPLC-DAD and HPLC-MS. J Food Composition and Analysis 17:385-396.

Berger MM (2005) Can oxidative damage be treated nutritionally? Clin Nutr 24:172-183.

Cano A, Acosta M and Arnao MB (2003) Hydrophilic and lipophilic antioxidant activity changes during on-vine ripening of tomatoes (Lycopersicon esculentum Mill). Postharvest Biol Technol 28:59-65.

Collins BH, Horská A, Hotten PM, Riddoch C and Collins AR (2001) Kiwifruit protects against oxidative DNA damage in human cells and in vitro. Nutr Cancer 39:148-153.

Cooke MS, Evans MD, Dizdaroglu M and Lunec J (2003) Oxidative DNA damage: Mechanisms, mutation, and disease. FASEB Journal 17:1195-1214.

Dearfield K, Jacobson-Kram D, Brown NA and Williams JR (1983) Evaluation of human hepatoma cell line as target cell in genetic toxicology. Mutat Res 108:437-449.

Delmanto RD, De Lima PLA, Suguia MM, Salvadori DMF, Da Eira AF, Speit G and Ribeiro LR (2001) Antimutagenic effect of Agaricus blazei Murril mushroom on the genotoxicity induced by cyclophosphamide. Mutat Res 496:15-21.

Dusinská M, Kazimirová A, Barancoková M, Beno M, Smolková B, Horská A, Raslová K, Wslová L and Collins AR (2003) Nutritional supplementation with antioxidants decreases chromosomal damage in humans. Mutagenesis 18:371-376.
Duthie SJ, Ma A, Ross MA and Collins AR (1996) Antioxidant supplementation decreases oxidative DNA damage in human lymphocytes. Cancer Res 56:1291-1295.

Edenharder R, Sager JW, Glatt H, Muckel E and Platt KL (2002) Protection by beverages, fruits, herbs, and flavonoids against genotoxicity of 2-acetylaminofluorene and 2-amino-1-methyl-6-phenylimidazo[4,5-b]pyridine (PhIP) in metabolically competent V79 cells. Mutat Res 521:57-72.

Edenharder R, Krieg H, Kottgen V and Platt KL (2003) Inhibition of clastogenicity of benzo[a]pyrene and of its trans-7,8dihydrodiol in mice in vivo by fruits, vegetables, and flavonoids. Mutat Res 537:169-181.

Erexson GL, Bryant MF, Kwanyuen P and Kligerman AD (1995) Bleomycin sulfate-induced micronuclei in human, rat and mouse peripheral blood lymphocytes. Environ Mol Mutagen 25:31-36.

Facioli NL and Gonçalves AG (1998) Modificação por via enzimática da composição triglicerídica do óleo de pequi (Caryocar brasiliense Camb). Química Nova 21:16-19 (Abstract in English).

Guterres ZR, Mantovani MS, Eira AF, Ribeiro LR and Jordão BQ (2005) Genotoxic and antigenotoxic effects of organic extracts of mushroom Agaricus blazei Murrill on V79 cells. Genet Mol Biol 28:458-463.

Gutteridge JMC (1981) Thiobarbituric acid-reactivity following iron-dependent free-radical damage to aminoacids and carbohydrates. FEBS Lett 128:343-346.

Halliwell B, Gutteridge JMC and Aruoma OI (1987) The deoxyribose method: A sample test tube assay for determination of rate constants for reaction of hydroxyl radical. Anal Biochem 165:215-219.

IARC (1981) Monographs on the Evaluation of the Carcinogenic Risk of Chemicals to Humans, V. 26: Some Antineoplastic and Immunosuppressive Agents. International Agency for Research on Cancer, Lyon, pp. 165-202.

Ikeuchi T and Sasaki M (1981) Differential inducibility of chromosome aberrations and sister-chromatid exchanges by indirect mutagens in various mammalian cell lines. Mutat Res 90:146-161.

Imlay JA and Linn S (1988) DNA damage and oxygen radical toxicity. Science 240:1302-1308.

Janero DJ (1990) Malondialdehyde and thiobarbituric acid-reactivity as diagnostic of lipid peroxidation and peroxidative tissue injury. Free Radic Biol Med 9:515-540.

Krishna G, Nath J, Peterson M and Ong T (1987) Cyclophosphamide-induced cytogenetic effects in mouse bone marrow and spleen cells in vivo and in vivo/in vitro assays Teratogen Carcinogen Mutagen 7:183-195.

Lee PJ, Min BS, Na RB, Na MK, Lee SM, Lee HK, Kim JG, Bae KH and Kang SS (2003) Stilbenes from the roots of Pleuropterus ciliinervis and their antioxidant activities. Phytochemistry 64:759-763.

Lopes GKB, Schulman HM and Hermes-Lima M (1999) Polyphenol tannic acd inhibits hydroxyl radicals formation from Fenton reaction by complexing ferrous ions. Biochem Biophys Acta 1472:142-152.

Liu X, Zhao J and Zheng R (2003) DNA damage of tumor-associated lymphocytes and total antioxidant capacity in cancerous patients. Mutat Res 539:1-8.

Mersch-Sudermann V, Kassie F, Bohmer S, Lu W-Q, Wohlfahrth R, Sobel R, Brunn HE, ElSohly MA, Ross AS and Stahl T 
(2004) Extracts of Toxicodendrn quercifolium caused genotoxicity and antigenotoxicity in bone marrow cells of CD1 mice. Food and Chem Toxicol 42:1611-1617.

Mohn GR and Ellenberger RJ (1976) Genetic effects of cyclophosphamide, isofosfamide and trofosfamide. Mutat Res 32:331-360.

Nascimento MA, Silva AK, França LCB, Quignard ELJ, López JA and Almeida MG (2006) Turnera ulmifolia L. (Turneraceae): Preliminary study of its antioxidant activity. Bioresources Technol 97:1387-1391.

Nogueira MEI, Passoni MH, Biso FI, Longo MC, Cardoso CRP, Santos LC and Varanda EA (2006) Investigation of genotoxic and antigenotoxic activities of Melampodium divaricatum in Salmonella typhimurium. Toxicol in Vitro 20:361-366.

Owen RW, Haubner R, Mier W, Giacosa A, Hull WE, Spiegelhalder B and Bartsch H (2003) Isolation, structure elucidation and antioxidant potential of the major phenolic flavonoid compounds in brined olive drupes. Food Chem Toxicol 41:703-717.
Povirk LF and Austin MJF (1991) Genotoxicity of bleomycin. Mutat Res 257:127-143.

Povirk LF (1996) DNA damage and mutagenesis by radiomimetic DNA-cleaving agents: Bleomycin, neocarzinostatin and other enediynes. Mutat Res 355:71-89.

Rodrigues-Amaya R (1999) Latin American food sources of carotenoids. Arch Latinoamericanos de Nutricion 49:74-84.

Savage JRK (1976) Classification and relationship of induced chromosomal structural changes. J Mol Genet 13:103-122.

Sausville EA, Stein RW, Peisach J and Horwitz SB (1978) Properties and products of degradation of DNA by bleomycin and iron (II). Biochem 17:2746-2754.

Schmid W (1975) The micronucleus test. Mutat Res 31:9-15.

Schiffl C, Zieres C and Zankl H (1997) Exhaustive physical exercise increases frequency of micronuclei. Mutat Res 389:343-346.

Sikic BI (1986) Biochemical and cellular determinants of bleomycin cytotoxicity. Cancer Surv 5:81-91.

www.epa.gov (2001) Health effects test guidelines - OPPTS 870.5395. Mammalian erythrocyte micronucleus test. Accessed in January 24.

Associate Editor: Catarina S. Takahashi 